\title{
Temperament and Defense Mechanism Patterns of Patients with Depressive Disorder: In Comparison with or without Anxiety Symptom
}

\author{
Jin-Woo Kim, Seok-Ho Yoon, So-Hye Jo, Hye-Geum Kim, Seok-Heon Kang, and Bon-Hoon Koo \\ Department of Psychiatry, Yeungnam University Hospital, Daegu, Korea
}

\section{우울장애 환자의 기질 및 방어기제 양상: 불안 증상의 동반 유무에 따른 비교}

\author{
김진우 · 윤석호 · 조소혜· 김혜금 · 강석헌 · 구본훈
}

영남대학교병원 정신건강의학과

\begin{abstract}
Objectives: The objective of this study was to compare psychological characteristics in the patients of depressive disorder with or without anxiety. Methods: The study included 416 patients and divided into two groups (210 with anxiety and 206 without anxiety). These data were obtained from a database of patients who had visited the Yeungnam University Hospital's psychiatric department from April 2009 to March 2019. Levels of anxiety were rated by Korean version of the Beck Anxiety Inventory (BAI). Psychological characteristics between the two groups were compared using the Temperament and Character Inventory (TCI) and the Defense Style Questionnaire (DSQ). Also, a multiple regression analysis was conducted to investigate the effects of temperament, character, and defense mechanisms on comorbidity of anxiety. Results: No significant difference was noticed in demographic characteristics between the two groups. The comorbid anxiety group exhibited higher novelty seeking, harm avoidance, self-transcendence but lower reward dependence, self-directedness, cooperativeness. The comorbid anxiety group used defense style such as maladaptive, image-distortion, self-sacrificing more frequently. Multiple regression analysis showed that harm avoidance, self-directedness, self-transcendence, defense style such as maladaptive, image-distortion, adaptive significantly affected the severity of anxiety. Logistic regression analysis showed that self-transcendence and defense style such as maladaptive, image-distortion, adaptive significantly affected the comorbidity of anxiety. Conclusion: These findings would be useful in understanding patients of depressive disorder with anxiety. Various psychotherapies can anticipate the prognosis of depressive patients and establish the plan of treatment.

Psychoanalysis 2020;31(4):70-80
\end{abstract}

KEY WORDS: Depressive disorder · Anxiety $\cdot$ Temperament $\cdot$ Character $\cdot$ Defense mechanism.

Received: September 16, 2020 Revised: September 23, 2020 Accepted: September 28, 2020

Address for correspondence: Bon-Hoon Koo, MD, PhD

Department of Psychiatry, Yeungnam University Hospital, 170 Hyeonchung-ro, Nam-gu, Daegu 42415, Korea

Tel: +82-53-620-3343, Fax: +82-53-657-3921, E-mail: vijnana@chol.com

\section{서 론}

우울장애는 정신건강의학과 외래에서 가장 흔하게 볼 수 있는 정신질환이다. 그 유병률은 국가 및 연구에 따라 차이가 있으나, 미국에서 주요우울장애의 유병률은 약 $7.1 \%$ 로 확인 되었으며 세계적으로 주요우울장애의 평생유병률은 약 $16.6 \%$ 에 달하는 것으로 조사되었다(Compton 등 2006; Kes-

This is an Open Access article distributed under the terms of the Creative Commons Attribution Non-Commercial License (https://creativecommons.org/licenses/by-nc/4.0) which permits unrestricted non-commercial use, distribution, and reproduction in any medium, provided the original work is properly cited. sler 등 2005). 국내에서도 전체 인구의 약 $5.6 \%$ 가 우울장애를 않고 있는 것으로 알려져 있다(Korea Centers for Disease Control \& Prevention 2018).

이러한 우울장애 환자 중 많은 수에서 불안 증상이 동반 되는데, 연구에 따르면 일반 인구에서의 불안장애 평생유병 률이 $28.8 \%$ 인 것에 비해 우울장애 환자에서 불안장애가 동 반될 평생유병률은 약 $45.7 \%$ 정도로 보고되었다(Kessler 등 2005; Kessler 등 2015). 이는 우울장애의 병력 자체가 불안 장애 발생의 위험요인이 될 수 있음을 시사한다. 이에 따라 우울장애와 불안장애가 동반되는 위험요인에 대한 연구가 진행되었는데, 그 결과 여성, 젊은 나이(25 34세), 낮은 교육 
수준, 독거, 무직, 부모의 정신과 과거력, 유년기 트라우마 등의 요인이 우울장애와 불안장애 각각의 발생위험을 높이 는 것으로 확인되었다(de Graaf 등 2002). 또한 심한 불안 증 상이 동반된 우울장애 환자는 그렇지 않은 우울장애 환자에 비해 이른 발병, 자살시도율의 증가, 낮은 학업성취, 높은 실 직률 등을 보이는 것이 여러 연구를 통해 알려져 있다(Belzer 과 Schneier 2004; Kessler 등 2005; Novick 등 2005; Wittchen 등 2000). 우울장애 환자의 치료반응에 대한 대규모 연구 결과, 심한 불안 증상이 동반된 우울장애 환자는 약물치료의 반응과 완치율이 감소하고 치료에 걸리는 시간이 증가하는 등, 보다 만성화되는 경향이 나타났다(Farabaugh 등 2012; Fava 등 2008; Novick 등 2005; Rush 등 2006).

이와 같이 우울장애 환자에 있어서 불안 증상의 동반은 매우 큰 의미를 가지고 있으며 이에 대한 연구들도 많이 이루 어져 있다. 불안 증상이 동반된 우울장애 환자는 동반되지 않 은 우울장애 환자에 비해 높은 위험회피가 관찰되었으며 위 험회피의 유전요인인 catechol-O-methyltransferase Met158 과 brain derived neurotrophic factor Met66가 높게 나타났다 (Enoch 등 2008). 우울과 불안 증상은 뇌내 신경전달물질 작 용의 측면에서도 연결 고리를 갖고 있다. 세로토닌의 부족은 우울 증상을 유발하며(Coppen 1967; Hogenelst 등 2016), 특히 그중에서도 5-HT1(5-HT1A, 5-HT1D) 수용체와 5-HT2(5$\mathrm{HT} 2 \mathrm{~A}, 5-\mathrm{HT} 2 \mathrm{C})$ 수용체의 이상이 우울장애의 발생에 중요한 역할을 한다는 것이 확인되었다(Hamon과 Blier 2013; $\mathrm{Nau}^{-}$ tiyal과 Hen 2017). 또한 편도체의 5-HT2A 수용체 작용에 이 상이 생길 경우 불안과 불면 증상이 발생한다(Bystritsky 등 2008). 노르에피네프린 역시 우울 및 불안 증상과 밀접한 연 관이 있는 것으로 알려져 있는데, 노르에피네프린의 감소가 우울 증상 발생에 영향을 주며(Bystritsky 등 2008) 범불안장 애 환자에서는 노르에피네프린의 증가가 관찰되었다(Homan 등 2015; Reader 등 2015). 도파민 뉴런의 기능 저하는 우울 증상을 유발하며(Dunlop과 Nemeroff 2007; Kasch 등 2002) 주요우울장애 환자들은 건강한 대조군에 비해 뇌척수액에서 도파민 대사물의 수치가 낮게 관찰되었다(Jokinen 등 2007). 사회불안장애 환자의 경우 선조체 내 도파민 전달체 밀도 및 도파민 수용체 결합이 감소되어 있었다(Schneier 등 2000; Shin과 Liberzon 2010).

Cloninger는 심리생물학적 모델을 통해 한 개인의 인격 (personality)을 기질(temperament)과 성격(character)의 두 가지 요소로 구분했다. 기질은 자극에 대한 개인의 정서적인 반응경향으로 유전적인 요인이 강해 거의 변화하지 않는 특 성을 지닌다. 성격은 개인의 가치관이나 스스로에 대한 자기 개념의 특성을 나타낸 것으로 기질에 바탕을 두고 경험과
학습을 통해 형성된다(Cloninger 등 1993). 많은 연구들을 통해 이러한 기질과 성격이 개인의 감정적 경험이나 행동 패턴, 증상의 정도에 영향을 준다는 사실이 밝혀졌다. 기존 연구에서 위험회피가 우울 및 불안 증상과 연관되어 있으며 자율성은 우울 및 불안과 부적 상관관계를 보인다는 것이 확인되었다(Jylhä와 Isometsä 2006). 또한 우울장애나 불안 장애의 병력이 있는 집단에서 위험회피가 높고 자율성이 낮 게 나온다는 연구 결과도 있었으며(Minelli 등 2009) 다른 연 구에서는 낮은 사회적 민감성, 인내력, 자율성, 연대감, 자기 초월이 우울장애와 연관성을, 높은 자극추구, 위험회피, 인 내력, 자기초월과 낮은 자율성이 불안장애와 연관되어 있었 다(Matsudaira와 Kitamura 2006). 86명의 우울장애 환자와 86명의 정상 대조군을 대상으로 한 연구에서는 높은 위험회 피가 우울장애와 연관이 있었고, 낮은 자율성이 불안 증상의 동반과 연관되어 있었다(de Winter 등 2007).

방어기제는 스트레스가 될 수 있는 외부자극으로부터 내면 의 불안을 감소시키기 위한 무의식적 작용을 말한다(Freud 1946). 방어기제는 스트레스 상황에서 개인이 어떻게 그에 대응하는가를 나타내는 중요한 요인으로 생각되고 있으며 마찬가지로 정신질환의 발생 및 증상의 종류나 정도에 영향 을 주는 것으로 알려져 있다. 기존 연구를 통해 우울장애 환 자가 불안장애 환자에 비해 미성숙한 방어유형을 사용하는 경향이 더 큰 것으로 확인되었다(Colovic 등 2016). 다른 연 구에서 불안장애와 우울장애 환자는 정상 대조군에 비해 미 성숙한 방어유형 점수가 높게 측정되었으며, 특히 불안장애 환자는 우울장애 및 정상 대조군과 비교하여 신경증적 방어 유형 점수가 높았다(Spinhoven과 Kooiman 1997).

이와 같이 우울장애와 불안장애 각각에 대한 연구들은 많 이 이루어지고 있으나, 우울장애 환자 중에서 불안 증상의 동반 여부에 초점을 맞춘 연구는 많지 않으며 그 규모도 적 은 것으로 보인다. 또한 기질과 방어유형을 같이 이용한 연 구 역시 그 수가 많지 않다. 따라서 우울장애의 예후와 치료 에 있어서 중요한 요인이 되는 불안 증상의 동반에 대해 개 인의 기질과 성격, 방어기제의 유형이 어떻게 영향을 주는가 를 알 수 있다면 우울장애 환자의 평가와 치료에 있어서 큰 도움이 될 수 있을 것이다. 이에 본 연구는 우울장애로 내원 한 정신건강의학과 환자들을 대상으로 불안 증상의 동반 유 무에 따른 기질과 성격, 방어기제 유형의 차이가 있는지를 확인하고, 이러한 차이가 불안 증상에 미치는 영향에 대해 알아보고자 하였다. 


\section{대상 및 방법}

\section{연구 대상}

본 연구는 2009년 4월부터 2019년 3월까지 10년간 영남대 학교병원 정신건강의학과를 방문한 18 65세의 환자 중 정 신질환 진단 및 통계 편람 4판(Diagnostic and Statistical Manual of Mental Disorders-fourth edition-text revision, DSM-IV-TR)과 DSM-5의 진단에 따라 우울장애에 해당되 는 환자들을 대상으로 하였다. 우울장애는 주요우울장애, 기 분부전장애 및 지속성 우울장애, 달리 명시된 우울장애, 명 시되지 않은 우울장애를 포함하였다. 연구는 우울장애 환자 들 중 심리검사에 참여 가능한 환자들을 대상으로 하였으며, 신경발달장애, 조현병 스펙트럼 장애, 양극성 장애, 인지기능 장애가 동반된 환자들과 기질적인 원인에 의한 환자들은 제 외하였다. 최종적으로 416명이 연구에 포함되었으며 벡 불 안척도(Beck Anxiety Inventory, BAI) 점수가 26점 이상인 210 명을 심한 불안이 동반된 집단, BAI 25점 이하인 206명 을 그렇지 않은 집단으로 구분하여 연구를 진행하였다.

\section{연구 방법}

본 연구는 후향적 연구로 연구 대상자들의 병록지와 심리 검사 결과를 근거로 자료를 수집하였다. 이에 따라 동의서 면제사유에 해당되어 대상자의 동의는 받지 않았으며, 영남 대학교병원 임상연구윤리위원회의 승인하에 연구가 진행되 었다(YUMC 2015-12-020).

\section{측정 도구}

본 연구에서는 환자의 불안 증상의 정도와 기질 및 성격, 그리고 방어기제 유형을 확인하기 위해 아래와 같은 측정도 구를 사용하였다.

\section{벡 불안척도(BAI)}

$\mathrm{BAI}$ 는 불안 증상의 심각도를 측정하기 위해 개발된 평가 도구로 1997년 한국어판으로 번안되었다. BAI는 총 21문항 으로 구성되어 있으며 불안 증상의 정도를 0 4점 사이의 점 수로 나타내도록 되어 있다. 결과적으로 얻게 된 0 63점 사 이의 점수를 0 7점은 정상, 8 15점은 경도, 16 25점은 중등 도, 26점 이상은 중증으로 분류한다(Beck 등 1988; Yook과 Kim 1997).

기질 및 성격 검사(Temperament and Character Inventory, $\mathrm{TCI})$

기질 및 성격 검사는 Cloninger의 정신생물학적 인성모델
(1993)을 기반으로 한 개인의 인격을 평가하기 위한 검사로, 유전적 요인인 기질과 환경적 요인인 성격을 구분하여 측정 한다. 본 연구에서는 TCI-Revised-Short version(TCI-RS) 을 한국어로 변역 및 표준화한 한국판 기질 및 성격 검사를 사용하였다(Sung 등 2002). 기질 및 성격 검사는 총 140 문 항이며 0 4점 사이의 점수를 선택하도록 한다. 결과는 자극 추구(novelty seeking), 위험회피(harm avoidance), 사회적 민감성(reward dependence), 인내력(persistence)의 네 가지 기질차원과, 자율성(self-directedness), 연대감(cooperativeness), 자기초월(self-transcendence)의 세 가지 성격차원을 합하여 총 일곱 가지 기준에 따라 분류된다.

이 일곱 가지 기준은 다시 몇 개의 소항목으로 분류되는 데, 자극추구는 탐색적 흥분(exploratory excitability), 충동 성(impulsivity), 무절제(extravagance), 자유분방(disorderliness)의 4개 항목으로 나뉘며, 위험회피는 예기불안(anticipatory worry), 불확실성에 대한 두려움(fear of uncertainty), 낮선 사람에 대한 수줍음(shyness with stranger), 쉽게 지침 (fatigability)의 4개 항목으로 나뉜다. 사회적 민감성은 정서 적 감수성(sentimentality), 정서적 개방성(openness to warm communication), 친밀감(attachment), 의존(dependence)의 4개, 그리고 인내력은 근면(eagerness of effort), 끈기(work hardness), 성취에 대한 야망(ambition), 완벽주의(perfectionism)의 4개 항목으로 나뉜다. 자율성 척도는 책임감(responsibility), 목적의식(purposefulness), 유능감(resourcefulness), 자기수용(self-acceptance), 자기일치(self-congruence) 의 5 개, 연대감 척도는 타인수용(social acceptance), 공감 (empathy), 이타성(helpfulness), 관대함(compassion), 공평 (pure hearted principle)의 5개, 자기초월은 창조적 자기망각 (creative self-forgetfulness), 우주만물과의 일체감(transpersonal identification), 영성수용(spiritual acceptance)의 3개 항목으로 나뉜다(Cloninger 등 1993; Cloninger 등 1994).

\section{방어유형 설문지(Defense Style Questionnaire, DSQ)}

$\mathrm{DSQ}$ 는 자아의 방어유형을 평가하기 위해 Bond와 Vail$\operatorname{lant(1986)ㄱㅏ~ㄱㅐㅂㅏㄹㅎㅏㄴ~ㅈㅏㄱㅏㅂㅗㄱㅗㅅㅣㄱ~ㄱㅓㅁㅅㅏㄷㅗㄱㅜㄹㅗ,~ㅂㅗㄴ~ㅇㅕㄴㄱㅜㅇㅔㅅㅓㄴㅡㄴ~}$ 한국어로 표준화된 방어유형 설문지를 사용하였다. 검사는 다양한 방어기제의 의식적 파생물을 기술하는 78 개 문항과 11 개의 허위성 문항으로 구성되어 있으며, 피검자가 일치하 는 정도에 따라 1 (일치하지 않음)부터 9(전적으로 일치함)까 지의 숫자로 나타내도록 되어 있다. 방어유형(defense style) 은 여러 개의 방어기제(defense)들로 구성되고, 방어의 성숙 도에 따라서 비적응형(maladaptive), 표상왜곡형(imagedistortion), 희생형(self-sacrificing), 적응형(adaptive)으로 
나눌 수 있다. 본 연구에서 사용된 DSQ는 신경증적 부정 (neurotic denial), 비망상적 투사(nondelusional projection), 수동공격성(passive aggression), 행동화(acting out), 분열 (splitting of other's image), 투사적 동일시(projective identification), 전지전능(omnipotence), 취소(undoing), 친밀감(affiliation), 신체화(somatization), 건강염려증(hypochondriasis)의 방어기제에 대해 평가하도록 설계되어 있다(Andrews 등 1993; Bond와 Vaillant 1986; Chung 등 1993).

\section{통계분석}

연구 대상자의 인구통계학적 정보를 파악하고 집단 사이에 유의미한 차이가 있는지 확인하기 위해 독립표본 $\mathrm{t}$ 검정, $\chi^{2}$ 혹은 Fisher's 정확검정을 실시하였다. 또한 집단 사이에 TCI 및 $\mathrm{DSQ}$ 결과의 차이를 확인하기 위해 독립표본 $\mathrm{t}$ 검정을 실 시하였다. TCI와 DSQ가 BAI에 미치는 영향을 알아보기 위 해 다중회귀분석을 시행하였다. 그리고 $\mathrm{TCI}$ 와 DSQ가 두 집 단 간의 차이에 미치는 영향을 확인하기 위해 로지스틱 회귀 분석을 실시하였다. 또한 통계학적 유의성을 확인하기 위해 $\mathrm{p}<0.05$ 를 유의성의 기준으로 설정하였다. 이상의 통계분석 을 위해 IBM SPSS Statistics 25.0(IBM Corp., Armonk, NY, USA)를 사용하였다.

\section{결 과}

\section{인구학적 및 임상적 특성}

연구 대상자의 평균 연령은 36.15세(standard deviation $[\mathrm{SD}]=14.29)$ 였으며, 심한 불안 증상이 동반된 집단의 평균 연령은 35.25세 $(\mathrm{SD}=13.61)$, 그렇지 않은 집단은 37.07세 $(\mathrm{SD}=14.93)$ 였다. 두 집단의 평균 연령은 통계적으로 유의한 차이가 없었다. 이 외에도 성별, 결혼 상태, 교육수준, 직업, 입원력, 유병기간, 자살력에서 집단 사이에 유의한 차이가 없는 것으로 나타났다. 전체 연구 대상자의 평균 $\mathrm{BAI}$ 점수 는 25.79점 $(\mathrm{SD}=12.96)$ 이었으며, 심한 불안이 동반된 집단의 평균 $\mathrm{BAI}$ 점수는 36.35 점 $(\mathrm{SD}=8.32)$, 그렇지 않은 집단의 평 균 $\mathrm{BAI}$ 점수는 15.02점 $(\mathrm{SD}=6.20)$ 이었다 $(\mathrm{p}<0.01)$ (Table 1) .

\section{두 집단 간의 TCI 점수 비교}

두 집단 간의 비교 결과, 심한 불안 증상이 동반된 집단에 서 자극추구 $(\mathrm{p}<0.01)$ 와 위험회피 $(\mathrm{p}<0.01)$, 자기초월 $(\mathrm{p}<$ $0.01)$ 이 유의하게 높게 나타났다. 반대로 사회적 민감성 $(\mathrm{p}=$ $0.03)$ 과 자율성 $(\mathrm{p}<0.01)$, 연대감 $(\mathrm{p}<0.01)$ 은 심한 불안 증상 이 동반되지 않은 집단에서 유의하게 더 높았다. 세부요인을 보았을 때 자극추구의 하위요인 중에서는 충동성 $(\mathrm{p}<0.01)$
과 무절제 $(\mathrm{p}<0.01)$ 가, 위험회피의 하위요인 중에서는 예기 불안 $(\mathrm{p}<0.01)$, 불확실성에 대한 두려움 $(\mathrm{p}<0.01)$, 수줍음 $(\mathrm{p}=$ $0.02)$, 쉽게 지침 $(\mathrm{p}<0.01)$ 이, 자기초월의 하위요인 중에서는 창조적 자기망각 $(\mathrm{p}<0.01)$, 우주만물과의 일체감 $(\mathrm{p}=0.04)$, 영성수용 $(\mathrm{p}=0.02)$ 이 심한 불안이 동반된 집단에서 유의하게 더 높았다. 반대로 사회적 민감성의 하위요인 중 친밀감 $(\mathrm{p}<$ $0.01)$, 인내력의 하위요인 중 근면 $(\mathrm{p}<0.01)$, 자율성의 하위요 인 중 책임감 $(\mathrm{p}<0.01)$, 목적의식 $(\mathrm{p}<0.01)$, 유능감 $(\mathrm{p}<0.01)$, 자기수용 $(\mathrm{p}<0.01)$, 자기일치 $(\mathrm{p}<0.01)$, 연대감의 하위요인 중 타인수용 $(\mathrm{p}<0.01)$, 관대함 $(\mathrm{p}=0.03)$ 은 심한 불안이 동반되지 않은 집단에서 유의하게 더 높은 것으로 나타났다. 특히 인내 력 차원은 그 자체로서는 두 집단 사이에 유의한 차이가 보 이지 않았으나 그 하위요인 중 하나인 근면은 심한 불안 증 상이 동반되지 않은 집단에서 유의하게 더 높은 것으로 나 타났다(Table 2).

\section{두 집단 간의 DSQ점수 비교}

방어기제 사용 양상을 비교했을 때, 심한 불안 증상이 동 반된 집단에서 비적응성 $(\mathrm{p}<0.01)$, 표상왜곡 $(\mathrm{p}<0.01)$, 자기 희생 $(\mathrm{p}=0.04)$ 의 방어유형이 유의하게 높은 것으로 나타났다. 구체적인 방어기제 사용을 보면 심한 불안이 동반된 집단에 서 신경증적 부정 $(\mathrm{p}<0.01)$, 비망상적 투사 $(\mathrm{p}<0.01)$, 행동화 $(\mathrm{p}<0.01)$, 전능감 $(\mathrm{p}<0.01)$, 취소 $(\mathrm{p}=0.02)$, 친밀감 $(\mathrm{p}<0.01)$ 의 방어기제 사용이 유의하게 더 높은 것으로 나타났다. 반대로 투사적 동일시는 심한 불안이 동반되지 않은 집단에서 더 잦 은 것으로 나타났다( $\mathrm{p}=0.02)$ (Table 3$)$.

\section{TCI와 DSQ가 BAI에 미치는 영향에 대한 다중회귀분석}

기질과 성격 및 방어유형이 불안 증상에 미치는 영향을 알 아보기 위해 BAI를 기준으로 다중회귀분석을 시행하였다. 기질과 성격요인 중에서는 위험회피 $(\mathrm{p}=0.04)$ 와 인내력 $(\mathrm{p}=$ $0.04)$, 자기초월 $(\mathrm{p}<0.01)$ 이 BAI 점수 증가에 유의하게 영향을 주며 자율성 $(\mathrm{p}<0.01)$ 은 $\mathrm{BAI}$ 감소에 유의한 영향을 주는 것으 로 나타났다. 방어기제 유형 중에서는 비적응성 $(\mathrm{p}<0.01)$, 표 상왜곡 $(\mathrm{p}<0.01)$ 방어유형은 $\mathrm{BAI}$ 점수를 유의하게 증가시켰 고, 적응성 $(\mathrm{p}<0.01)$ 방어유형은 $\mathrm{BAI}$ 점수를 유의하게 감소 시키는 경향을 보였다. 상세 방어기제 중 신경증적 부정 $(\mathrm{p}<$ $0.01)$ 과 행동화 $(\mathrm{p}<0.01)$ 는 $\mathrm{BAI}$ 점수를 유의하게 높이고, 수 동공격성 $(\mathrm{p}<0.01)$ 과 투사적 동일시 $(\mathrm{p}=0.04)$ 는 $\mathrm{BAI}$ 점수를 유의하게 낮추는 경향이 나타났다(Table 4). 
Table 1. Demographic data of patients between groups

\begin{tabular}{|c|c|c|c|c|}
\hline Variables & $\mathrm{HA}(\mathrm{n}=210)$ & LA $(n=206)$ & Total $(n=416)$ & $\mathrm{p}$ \\
\hline Age (years) & $35.25 \pm 13.61$ & $37.07 \pm 14.93$ & $36.15 \pm 14.29$ & 0.19 \\
\hline Gender & & & & 1.00 \\
\hline Male & $105(50.0)$ & $103(50.0)$ & $208(50.0)$ & \\
\hline Female & $105(50.0)$ & $103(50.0)$ & $208(50.0)$ & \\
\hline Marital status & & & & 0.68 \\
\hline Unmarried & $104(49.50)$ & $95(46.10)$ & $199(47.90)$ & \\
\hline Married & $76(36.20)$ & $85(41.30)$ & $161(38.70)$ & \\
\hline Divorced & $7(3.30)$ & $8(3.90)$ & $15(3.60)$ & \\
\hline Remarried & $2(1.00)$ & $3(1.40)$ & $5(1.20)$ & \\
\hline Separation & $2(1.00)$ & $4(1.90)$ & $6(1.40)$ & \\
\hline Other & $2(1.00)$ & $1(0.50)$ & $3(0.70)$ & \\
\hline Non respondents & $17(8.00)$ & $10(4.90)$ & $27(6.50)$ & \\
\hline Academic background & & & & 0.92 \\
\hline Elementary & $4(1.90)$ & $5(2.40)$ & $9(2.20)$ & \\
\hline Middle & $8(3.80)$ & $5(2.40)$ & $13(3.10)$ & \\
\hline High & $73(34.80)$ & $68(33.00)$ & $141(33.90)$ & \\
\hline University & $66(31.40)$ & $65(31.60)$ & $131(31.50)$ & \\
\hline Graduate school & $3(1.40)$ & $5(2.40)$ & $8(1.90)$ & \\
\hline None respondent & $56(26.70)$ & $58(28.20)$ & $114(27.40)$ & \\
\hline Occupation & & & & 0.53 \\
\hline Office worker & $11(5.20)$ & $13(6.30)$ & $24(5.80)$ & \\
\hline Technician & $4(1.90)$ & $6(2.90)$ & $10(2.40)$ & \\
\hline Enterpriser & $2(1.00)$ & $0(0.00)$ & $2(0.50)$ & \\
\hline Self-employed & $13(6.20)$ & $19(9.20)$ & $32(7.70)$ & \\
\hline Professional & $4(1.90)$ & $4(2.00)$ & $8(1.90)$ & \\
\hline Religious & $1(0.50)$ & $0(0.00)$ & $1(0.20)$ & \\
\hline Service & $12(5.70)$ & $10(4.90)$ & $22(5.30)$ & \\
\hline Agricultural/Fisheries & $5(2.40)$ & $12(5.80)$ & $17(4.10)$ & \\
\hline Housewife & $31(14.80)$ & $32(15.50)$ & $63(15.10)$ & \\
\hline Day labor & $5(2.40)$ & $7(3.40)$ & $12(2.90)$ & \\
\hline Unemployed & $56(26.70)$ & $55(26.70)$ & $111(26.70)$ & \\
\hline Student & $39(18.60)$ & $33(16.00)$ & $72(17.30)$ & \\
\hline Other & $12(5.70)$ & $7(3.40)$ & $19(4.60)$ & \\
\hline Non-respondents & $15(7.10)$ & $8(3.90)$ & $23(5.50)$ & \\
\hline Hospitalization & $0.45 \pm 1.94$ & $0.22 \pm 0.78$ & $0.34 \pm 1.49$ & 0.12 \\
\hline Onset period & $49.67 \pm 49.08$ & $53.97 \pm 66.93$ & $51.80 \pm 58.58$ & 0.46 \\
\hline Suicidal history & & & & 0.10 \\
\hline Yes & $16(7.60)$ & $8(3.90)$ & $24(5.80)$ & \\
\hline No & $194(92.40)$ & $198(96.10)$ & $392(94.20)$ & \\
\hline BAI & $36.35 \pm 8.32$ & $15.02 \pm 6.20$ & $25.79 \pm 12.96$ & $<0.01$ \\
\hline
\end{tabular}

Values are presented as mean \pm standard deviation or $\mathrm{n}(\%)$ unless otherwise indicated. HA: high anxiety group, LA: low anxiety group, BAI: Beck Anxiety Inventory

TCI와 DSQ가 우울장애 환자에서 불안 증상의 동반에 미치는 영향에 대한 로지스틱 회귀분석

우울장애 환자 중 심한 불안 증상이 동반된 집단과 동반 되지 않은 집단을 구분하는 데에 기질과 성격 및 방어유형이 어떻게 영향을 주는지 확인하기 위해 로지스틱 회귀분석을
시행하였다. 기질과 성격요인 중에서는 자기초월이 불안 증 상의 동반에 영향을 미치는 것으로 확인되었으며 설명력은 $17.4 \%$, 분류정확도 $63.7 \%$, odds ratio 0.95 였다 $(\mathrm{p}<0.01)$. 방어 유형 중에서는 비적응성, 표상왜곡, 적응성 방어유형이 불안 증상의 동반에 영향을 주는 것으로 나타났다. 설명력은 
Table 2. Comparisons of $\mathrm{TCl}$ Index and subscales between groups

\begin{tabular}{|c|c|c|c|c|}
\hline Variables & $\mathrm{HA}(\mathrm{n}=210)$ & LA $(n=206)$ & $\mathrm{t}$ & $\mathrm{p}$ \\
\hline Novelty seeking & $55.44 \pm 13.36$ & $51.44 \pm 11.31$ & 2.94 & $<0.01$ \\
\hline Exploratory excitability & $7.03 \pm 4.12$ & $7.45 \pm 3.67$ & -0.98 & 0.33 \\
\hline Impulsiveness & $9.87 \pm 4.27$ & $8.02 \pm 3.77$ & 4.19 & $<0.01$ \\
\hline Extravagance & $9.60 \pm 4.76$ & $7.28 \pm 4.29$ & 4.66 & $<0.01$ \\
\hline Disorderliness & $7.55 \pm 4.37$ & $7.17 \pm 4.02$ & 0.82 & 0.41 \\
\hline Harm avoidance & $72.17 \pm 11.57$ & $65.69 \pm 11.79$ & 5.06 & $<0.01$ \\
\hline Anticipatory worry & $15.85 \pm 4.83$ & $12.91 \pm 4.47$ & 5.77 & $<0.01$ \\
\hline Fear of uncertainty & $14.04 \pm 3.00$ & $12.72 \pm 3.45$ & 3.74 & $<0.01$ \\
\hline Shyness & $13.31 \pm 4.78$ & $12.02 \pm 4.88$ & 2.44 & 0.02 \\
\hline Fatigability & $16.30 \pm 2.79$ & $14.31 \pm 3.53$ & 5.69 & $<0.01$ \\
\hline Reward dependence & $40.78 \pm 14.37$ & $43.91 \pm 12.30$ & -2.13 & 0.03 \\
\hline Sentimentality & $10.32 \pm 4.01$ & $10.70 \pm 3.75$ & -0.91 & 0.36 \\
\hline Openness to warm communication & $7.30 \pm 4.08$ & $7.99 \pm 3.83$ & -1.60 & 0.11 \\
\hline Attachment & $7.81 \pm 4.28$ & $9.43 \pm 4.25$ & -3.47 & $<0.01$ \\
\hline Dependence & $9.61 \pm 3.19$ & $9.57 \pm 3.31$ & 0.11 & 0.91 \\
\hline Persistence & $37.23 \pm 13.41$ & $38.67 \pm 11.46$ & -1.05 & 0.29 \\
\hline Eagermess of effort & $7.80 \pm 3.95$ & $9.28 \pm 3.98$ & -3.41 & $<0.01$ \\
\hline Work hardened & $6.51 \pm 3.94$ & $6.90 \pm 3.60$ & -0.93 & 0.35 \\
\hline Ambitious & $8.20 \pm 4.47$ & $8.08 \pm 4.03$ & -0.25 & 0.80 \\
\hline Perfectionist & $8.43 \pm 4.73$ & $8.07 \pm 4.18$ & -0.74 & 0.46 \\
\hline Self directedness & $29.13 \pm 11.15$ & $35.88 \pm 12.46$ & -5.22 & $<0.01$ \\
\hline Responsibility & $8.11 \pm 3.76$ & $10.19 \pm 3.87$ & -4.97 & $<0.01$ \\
\hline Purposeful & $6.27 \pm 3.51$ & $7.67 \pm 3.91$ & -3.44 & $<0.01$ \\
\hline Resourcefulness & $3.11 \pm 2.07$ & $4.20 \pm 2.35$ & -4.54 & $<0.01$ \\
\hline Self-acceptance & $2.02 \pm 1.73$ & $2.63 \pm 1.80$ & -3.16 & $<0.01$ \\
\hline Enlightened second nature & $7.12 \pm 3.83$ & $8.84 \pm 3.99$ & -4.02 & $<0.01$ \\
\hline Cooperativeness & $36.38 \pm 15.10$ & $41.24 \pm 13.55$ & -3.08 & $<0.01$ \\
\hline Social acceptance & $9.25 \pm 3.85$ & $11.61 \pm 3.18$ & -6.10 & $<0.01$ \\
\hline Empathy & $7.77 \pm 3.35$ & $8.18 \pm 3.19$ & -1.13 & 0.26 \\
\hline Helpfulness & $8.15 \pm 3.79$ & $8.67 \pm 3.34$ & -1.31 & 0.19 \\
\hline Compassion & $5.99 \pm 3.44$ & $6.78 \pm 3.32$ & -2.15 & 0.03 \\
\hline Pure-hearted conscience & $12.47 \pm 4.01$ & $13.06 \pm 3.69$ & 1.38 & 0.17 \\
\hline Self transcendence & $48.07 \pm 11.05$ & $44.28 \pm 8.73$ & 3.49 & $<0.01$ \\
\hline Self-forgetful & $10.88 \pm 5.20$ & $8.44 \pm 4.78$ & 4.44 & $<0.01$ \\
\hline Transpersonal identification & $5.53 \pm 4.20$ & $4.64 \pm 3.75$ & 2.04 & 0.04 \\
\hline Spiritual acceptance & $7.63 \pm 5.11$ & $6.41 \pm 4.03$ & 2.42 & 0.02 \\
\hline
\end{tabular}

Values are presented as mean \pm standard deviation unless otherwise indicated. TCI: Temperament and Character Inventory, HA: high anxiety group, LA: low anxiety group

$26.3 \%$, 분류정확도는 $69.4 \%$ 였으며, odds ratio는 비적응성 방 어유형이 $0.57(\mathrm{p}<0.01)$, 표상왜곡 방어유형이 $0.61(\mathrm{p}<0.01)$, 적응성 방어유형이 $1.38(\mathrm{p}<0.01)$ 이었다. 세부적으로는 신경 증적 부정과 수동공격성, 행동화 방어기제가 불안 증상의 동 반에 영향을 주는 것으로 나타났으며 설명력은 $17.9 \%$, 분류 정확도는 $65.5 \%$, odds ratio는 신경증적 부정이 $0.82(\mathrm{p}<0.01)$, 수동공격성이 $1.11(\mathrm{p}=0.03)$, 행동화가 $0.73(\mathrm{p}<0.01)$ 이었다 (Table 5).

\section{고 찰}

본 연구는 우울장애 환자 중 심한 불안 증상이 동반되는 집단과 그렇지 않은 집단 간의 기질과 성격 및 방어기제 유 형의 차이를 알아보고, 이러한 차이가 불안 증상의 동반에 미치는 영향을 알아보고자 하였다. 기질에 대한 비교에서 심 한 불안 증상이 동반된 집단이 자극추구와 위험회피는 높지 만 사회적 민감성은 낮은 것으로 나타났다. 이는 높은 위험 회피와 낮은 사회적 민감성이 우울 및 불안 증상과 연관되 
Table 3. Comparisons of defense mechanisms between groups

\begin{tabular}{|c|c|c|c|c|}
\hline Variables & $\mathrm{HA}(\mathrm{n}=210)$ & LA $(n=206)$ & $\mathrm{t}$ & $\mathrm{p}$ \\
\hline \multicolumn{5}{|l|}{ Cluster score } \\
\hline Maladaptive action & $5.15 \pm 1.07$ & $4.19 \pm 1.07$ & 9.00 & $<0.01$ \\
\hline Image distorting & $4.26 \pm 1.00$ & $3.49 \pm 1.00$ & 7.62 & $<0.01$ \\
\hline Self sacrificing & $4.07 \pm 1.44$ & $3.79 \pm 1.27$ & 2.02 & 0.04 \\
\hline Adaptive & $3.79 \pm 1.25$ & $3.96 \pm 1.18$ & -1.40 & 0.16 \\
\hline \multicolumn{5}{|l|}{ Defense mechanism } \\
\hline Neurotic denial & $3.62 \pm 1.84$ & $2.83 \pm 1.63$ & 4.51 & $<0.01$ \\
\hline Nondelusional projection & $3.80 \pm 1.40$ & $3.30 \pm 1.32$ & 3.70 & $<0.01$ \\
\hline Passive aggression & $6.55 \pm 2.34$ & $6.45 \pm 2.56$ & 0.38 & 0.71 \\
\hline Acting out & $6.93 \pm 1.53$ & $6.05 \pm 1.65$ & 5.56 & $<0.01$ \\
\hline Splitting of other image & $4.70 \pm 2.80$ & $4.40 \pm 2.72$ & 1.07 & 0.29 \\
\hline Projective identification & $4.24 \pm 2.67$ & $4.88 \pm 2.55$ & -2.45 & 0.02 \\
\hline Omnipotence & $5.68 \pm 1.93$ & $5.02 \pm 2.12$ & 3.23 & $<0.01$ \\
\hline Undoing & $3.58 \pm 2.44$ & $3.05 \pm 2.19$ & 2.26 & 0.02 \\
\hline Affiliation & $4.36 \pm 3.61$ & $3.41 \pm 3.30$ & 2.73 & $<0.01$ \\
\hline Somatization & $3.03 \pm 2.27$ & $3.58 \pm 2.16$ & 1.99 & 0.05 \\
\hline Hypochondriasis & $2.18 \pm 1.18$ & $2.19 \pm 1.10$ & -0.92 & 0.93 \\
\hline
\end{tabular}

Values are presented as mean \pm standard deviation unless otherwise indicated. HA: high anxiety group, LA: low anxiety group

Table 4. Multiple regression analysis on BAI with TCI, DSQ (cluster score and defense mechanism) respectively

\begin{tabular}{|c|c|c|c|c|c|c|}
\hline Variables & $\mathrm{B}$ & $\mathrm{SE}$ & $\beta$ & $\mathrm{t}$ & $\mathrm{F}$ & Adj $R^{2}$ \\
\hline TCI & & & & & $13.41^{\dagger}$ & 0.21 \\
\hline Novelty seeking & 0.01 & 0.06 & 0.01 & 0.22 & & \\
\hline Harm avoidance & 0.16 & 0.08 & 0.15 & $2.11^{*}$ & & \\
\hline Reward dependence & -0.07 & 0.06 & -0.07 & -1.08 & & \\
\hline Persistence & 0.15 & 0.07 & 0.14 & 2.12 & & \\
\hline Self directedness & -0.27 & 0.08 & -0.25 & $-3.18^{\dagger}$ & & \\
\hline Cooperativeness & -0.10 & 0.06 & -0.11 & -1.59 & & \\
\hline Self transcendence & 0.25 & 0.07 & -0.20 & $3.49^{\dagger}$ & & \\
\hline Cluster score & & & & & $48.22^{\dagger}$ & 0.32 \\
\hline Maladaptive action & 3.96 & 0.65 & 0.36 & $6.06^{\dagger}$ & & \\
\hline Image distorting & 2.97 & 0.74 & 0.25 & $4.01^{\dagger}$ & & \\
\hline Self sacrificing & 0.49 & 0.44 & 0.05 & 1.11 & & \\
\hline Adaptive & -2.27 & 0.50 & -0.21 & $-4.49^{\dagger}$ & & \\
\hline Defense mechanism & & & & & $11.01^{\dagger}$ & 0.21 \\
\hline Neurotic denial & 0.99 & 0.37 & 0.14 & $2.66^{\dagger}$ & & \\
\hline Nondelusional projection & 0.21 & 0.52 & 0.02 & 0.41 & & \\
\hline Passive aggression & -0.84 & 0.26 & -0.16 & $-3.28^{\dagger}$ & & \\
\hline Acting out & 2.79 & 0.42 & 0.35 & $6.62^{\dagger}$ & & \\
\hline Splitting of other image & 0.28 & 0.22 & 0.06 & 1.27 & & \\
\hline Projective identification & -0.47 & 0.23 & -0.95 & $-2.04^{*}$ & & \\
\hline Omnipotence & 0.51 & 0.31 & 0.08 & 1.66 & & \\
\hline Undoing & 0.50 & 0.27 & 0.09 & 1.85 & & \\
\hline Affiliation & 0.26 & 0.17 & 0.07 & 1.49 & & \\
\hline Somatization & 0.10 & 0.29 & 0.02 & 0.35 & & \\
\hline Hypochondriasis & -0.43 & 0.55 & -0.04 & -0.79 & & \\
\hline
\end{tabular}

${ }^{*} \mathrm{p}<0.05,{ }^{\dagger} \mathrm{p}<0.01$. BAI: Beck Anxiety Inventory, TCI: Temperament and Character Inventory, DSQ: Defense Style Questionnaire, SE: standard error 
JW Kim, et al.

Table 5. Multiple logistic regression analysis for TCI and DSQ (cluster score and defense mechanism) respectively

\begin{tabular}{|c|c|c|c|c|c|c|}
\hline Variables & $\mathrm{B}$ & SE & OR & Wald & $\chi^{2}$ & Nagelkerke $\mathrm{R}^{2}$ \\
\hline TCI & & & & & $46.63^{\dagger}$ & 0.17 \\
\hline Novelty seeking & -0.00 & 0.01 & 1.00 & 0.01 & & \\
\hline Harm avoidance & -0.03 & 0.01 & 0.97 & 3.36 & & \\
\hline Reward dependence & -0.01 & 0.01 & 1.01 & 0.29 & & \\
\hline Persistence & 0.00 & 0.01 & 0.99 & 0.12 & & \\
\hline Self directedness & 0.03 & 0.02 & 1.03 & 3.00 & & \\
\hline Cooperativeness & -0.01 & 0.01 & 1.01 & 1.35 & & \\
\hline Self transcendence & -0.05 & 0.01 & 0.95 & $10.43^{\dagger}$ & & \\
\hline Cluster score & & & & & $87.73^{+}$ & 0.26 \\
\hline Maladaptive action & -0.55 & 0.15 & 0.57 & $14.42^{\dagger}$ & & \\
\hline Image distorting & -0.49 & 0.17 & 0.61 & $8.72 *$ & & \\
\hline Self sacrificing & -0.09 & 0.09 & 0.92 & 0.85 & & \\
\hline Adaptive & 0.33 & 0.11 & 1.38 & $8.41^{*}$ & & \\
\hline Defense mechanism & & & & & $57.27^{\dagger}$ & 0.18 \\
\hline Neurotic denial & -0.20 & 0.07 & 0.82 & $7.77^{\dagger}$ & & \\
\hline Nondelusional projection & -0.04 & 0.10 & 0.97 & 0.14 & & \\
\hline Passive aggression & 0.11 & 0.05 & 1.11 & $4.74^{*}$ & & \\
\hline Acting out & -0.31 & 0.08 & 0.73 & $14.97^{\dagger}$ & & \\
\hline Splitting of other image & -0.03 & 0.04 & 0.97 & 0.67 & & \\
\hline Projective identification & -0.07 & 0.04 & 1.07 & 2.40 & & \\
\hline Omnipotence & -0.06 & 0.06 & 0.94 & 1.29 & & \\
\hline Undoing & -0.07 & 0.05 & 0.93 & 1.83 & & \\
\hline Affiliation & -0.03 & 0.03 & 0.97 & 1.03 & & \\
\hline Somatization & -0.03 & 0.06 & 0.97 & 0.30 & & \\
\hline Hypochondriasis & -0.08 & 0.10 & 1.08 & 0.56 & & \\
\hline
\end{tabular}

${ }^{*} \mathrm{p}<0.05,{ }^{\dagger} \mathrm{p}<0.01$. TCI: Temperament and Character Inventory, DSQ: Defense Style Questionnaire, SE: standard error, OR: odds ratio

어 있다는 기존의 연구 결과와 상당 부분 일치한다(Matsudaira와 Kitamura 2006). 기질은 유전적인 요인이 강하고 환 경에 의한 변화가 크지 않다는 기존 연구 결과를 함께 고려하 면, 자극추구와 위험회피가 불안 증상 동반의 위험요인으로 작용하였을 것이며 사회적 민감성은 보호요인으로 작용하였 을 것이라 추측할 수 있다(Heath 등 1994; Stallings 등 1996). 특히 자극추구와 위험회피가 모두 높은 경우 새로운 것에 대 한 추구와 위험에 대한 두려움이 상충하여 심리적 갈등을 유 발하고 이것이 내적인 불안으로 나타났을 것으로 해석할 수 있다(Cloninger 1986). 성격요인에서는 높은 자기초월이 심 한 불안 증상의 동반과 연관되어 있었고, 반대로 심한 불안 이 동반되지 않은 집단에서 자율성과 연대감이 높게 나타났 다. 특히 자기초월과 자율성에 대한 결과는 기존 연구와 맥 락을 같이 하고 있으며, 특히 그중에서 자율성 차원이 모든 하위요인에서 유의미한 차이를 보여 불안 증상의 동반과 깊 은 연관이 있을 것으로 생각된다. 본 연구와 유사한 형태의 2007년 연구에서도 자율성이 불안 증상의 동반에 연관된 것 으로 나타났다(de Winter 등 2007). 자율성이 높은 사람은
스스로를 자율적 개인으로 이해하고 자신이 선택한 목표와 가치를 이루기 위해 상황에 맞게 행동을 통제하고 조절할 수 있는 사람으로, 이러한 특성이 불안에 대처하는 능력으로 나타나기에 불안 증상에 대해 보호요인이 될 수 있을 것으 로 생각된다.

방어유형에 대한 비교에서 심한 불안 증상이 동반된 집단 에서 비적응성과 표상왜곡, 자기희생 방어유형의 사용이 높 게 나타났다. 이는 우울장애와 불안장애 모두에서 비적응성 방어유형이 두드러지게 나타난다는 기존의 연구 결과와 부 분적으로 일치하고 있다(Kennedy 등 2001). 이러한 미성숙 한 방어유형의 주된 사용으로 인해 외부 스트레스에 대한 적절한 대응이 이루어지지 못하여 우울 및 불안 증상이 나 타나게 되었다고 해석할 수 있으며, 동시에 대처능력의 저하 로 인해 우울 및 불안 증상이 더욱 심하게 나타나는 것으로 해석할 수 있다. 세부적인 방어기제 사용을 봤을 때 심한 불 안이 동반된 집단에서 신경증적 부정, 비망상적 투사, 행동 화, 전지전능, 취소, 친밀감의 방어기제 사용이 유의미하게 두드러졌으며 반대로 투사적 동일시와 신체화는 심한 불안 
증상이 동반되지 않은 집단에서 더 자주 사용되었다. 부정과 투사, 행동화의 방어기제의 잦은 사용은 내면의 갈등을 직면 하여 해소하지 못하고 미성숙한 형태로 대처하려 하고 있음 을 나타내며, 이로 인해 상대적으로 높은 불안이 동반되는 것으로 해석할 수 있다. 반대로 내적 혹은 외적 갈등으로 인 한 불안을 경험하고 있기에 이를 견디지 못하고 부정, 투사, 행동화를 통해 외부로 발산하고자 한다는 해석도 가능하다. 전지전능과 친밀감의 방어기제는 불안을 극복하기 위해 자 존감을 높이려는 보상심리나 타인과의 유대를 통해 도움을 얻고자 하는 것으로 해석될 수 있으며 취소 역시 같은 맥락 에서 자신의 행동이나 상황을 되돌리고자 하는 것으로 생각 된다. 투사적 동일시와 신체화는 심한 불안이 동반되지 않은 집단에서 두드러지게 나타났는데, 투사적 동일시는 자신의 불안을 뚜렷한 외부대상에게 전가함으로써 내적인 갈등을 외적인 갈등으로 변환한다는 측면으로 해석할 수 있고, 신체 화는 자신의 불안과 같은 감정을 인식하기보다는 신체증상 으로 표현하는 것으로 볼 수 있다. 다만 이러한 결과는 우울 장애 환자가 신체화, 평가절하, 격리의 방어기제를 주로 사용 한다는 기존 연구와는 다소 맞지 않는 모습을 보인다(Spinhoven과 Kooiman 1997). 이는 기존 연구에서는 불안 증상의 동반 여부와 무관하게 우울장애 환자를 대상으로 하였고, 본 연구는 우울장애 환자에서 불안 증상의 동반 여부에 따라 좀 더 세분한 집단을 대상으로 했기 때문에 차이가 생겼을 것으 로 생각된다. 또한 개별적인 방어기제 사용에 대해서는 연구 에 따라 그 결과가 상이하다는 점을 고려하면 문화적 특성 등 의 다른 요인들이 영향을 주는 것으로 생각된다.

기질과 성격 및 방어유형이 불안 증상의 심각도에 어떤 영향을 미치는지 알아보기 위해 시행한 다중회귀분석 결과 에서, 기질과 성격 중에서는 위험회피, 자기초월이 높은 불 안 증상에 영향을 주었으며 자율성은 낮은 불안 증상에 영 향을 주는 것으로 나타났다. 이는 높은 자극추구, 위험회피, 인내력, 자기초월과 낮은 자율성이 불안 장애와 연관되어 있 다는 2006년 연구(Jylhä와 Isometsä 2006; Matsudaira와 Kitamura 2006)와 낮은 자율성이 우울장애 환자에서 불안 증상의 동반과 연관되어 있다는 2007년 연구(de Winter 등 2007)와 부합하는 결과이다. 반면에 본 연구에서는 자극추 구의 영향이 의미가 있을 정도로 크게 나타나지 않았는데, 이는 자극추구가 위험회피와 함께 작용할 때 불안 증상을 유 발한다고 해석할 수 있다. 종합해 보면 위험회피의 기질 요 인이 불안 증상 경험의 큰 원인이 되고, 자율성의 성격 요인 이 내적 갈등이 불안으로 나타나는 것을 억제하는 보호작용 을 한다는 것을 강하게 시사한다. 불안 증상과 방어유형 사 이의 관계를 보았을 때 비적응성 방어유형, 표상왜곡 방어유
형의 사용이 더 심한 불안 증상과 연관되어 있었고 적응성 방어유형은 낮은 불안 증상과 연관되어 있었다. 이 역시 적 응성 방어유형과 비적응성 방어유형이 불안 증상에 미치는 영향에 대한 기존 연구와 일치하는 결과이며, 표상왜곡 방어 유형이 내적인 불안에 영향을 미칠 수 있음을 시사한다. 세 부적으로는 신경증적 부정, 행동화의 방어기제가 높은 불안 과 연관되어 있었고 수동공격성과 투사적 동일시는 낮은 불 안과 연관되어 있었다. 특히 부정, 행동화, 투사적 동일시는 두 집단 간의 비교분석에서도 유의미한 차이를 보였다는 점 에서 큰 의미를 갖는다.

우울장애 환자들에게서 불안 증상의 동반 유무를 구분함 에 있어 기질과 성격 및 방어유형의 영향을 알아보기 위해 시행한 로지스틱 회귀분석 결과, 기질과 성격 중에서는 자기 초월이 불안 증상의 동반에 유의미한 영향을 주는 것으로 나타났으나 그 영향력은 크지 않았다. 이는 자기초월이 높은 사람들이 유물적이고 객관적이기보다는 영적이고 감성적이 며, 스스로를 거대한 집단의 일부로 생각하는 경향을 보인다 는 점을 고려했을 때, 이러한 경향이 보이지 않는 불확실한 것과 초월적인 힘에 대한 염려를 일으켜 불안을 초래하는 것으로 해석할 수 있다. 교차분석이나 타 연구에서 연관성을 보였던 자극추구와 위험회피는 유의미한 영향력을 보이지 않았는데, 이는 앞서 말했듯이 자극추구와 위험회피가 함께 높을 경우 내적 갈등으로 인한 불안이 증가되는 것으로 해 석하면 개별 요인으로서의 영향을 분석한 로지스틱 회귀분 석에서 그 영향력이 유의미하지 않았을 것으로 생각된다. 방 어유형의 영향력에 대한 분석에서 비적응성 방어유형과 표 상왜곡 방어유형이 불안 증상의 동반에 큰 영향을 미치는 것 으로 나타났으며 적응성 방어유형은 그 반대의 영향력을 보 였다. 이러한 결과를 봤을 때 성숙한 방어유형이 불안을 적 절하게 해소하고 극복하는 데에 긍정적인 영향을 주고 미성 숙한 방어유형은 불안을 효과적으로 해소하지 못하거나 반 대로 불안을 유발할 수 있다고 해석된다. 세부적으로는 신경 증적 부정과 행동화가 불안 증상의 동반에 영향력을 가지고 있었고 수동공격성은 불안 증상이 동반되지 않도록 하는 영 향력을 보였다.

본 연구의 제한점은 다음과 같다. 첫 번째는 환자의 병록 지를 근거로 데이터를 수집한 후향적 연구이기 때문에 통제 된 실험에 비해 편향이 작용했을 가능성이 있다. 두 번째로 는 불안 증상의 동반 유무를 구분함에 있어 $\mathrm{BAI}$ 점수라는 다소 간소한 도구 하나만을 이용했다는 점이다. 대상자의 불 안이 일시적인지 지속적인지, 특이적인지 비특이적인지 등 의 요인을 고려하였다면 이를 심리검사 결과와 결부하여 보 다 다각적인 분석이 가능했을 것이다. 
결론적으로 본 연구를 통해 우울장애 환자 중 자극추구와 위험회피가 높은 환자, 그리고 자율성이 낮거나 자기초월이 높은 환자에서 심한 불안 증상이 동반될 위험이 높을 것이 라 추측할 수 있다. 또한 비적응성 방어유형과 적응성 방어 유형은 심한 불안 증상의 동반과 깊은 연관을 지님을 알 수 있었다. 특히 방어기제 유형에 따라 불안뿐만이 아니라 우울 등의 다른 증상 역시 영향을 받는다는 점을 고려할 때, 심한 불안이 동반된 우울장애 환자는 전반적인 정신건강의 영역 에서 미성숙한 경향을 보이며 더 심한 증상을 경험할 것이라 고 생각할 수 있다. 기존의 연구들과 본 연구의 결과를 종합 하여 볼 때 심한 불안이 동반된 우울장애와 그렇지 않은 우울 장애는 근본적으로 별개의 병태 생리를 지니기보다는 동일한 스펙트럼에 있어서 환자의 미성숙한 정도나 중증도의 차이를 가지는 것으로 생각할 수 있다. 이는 우울과 불안이 세로토닌 과 노르에피네프린, 도파민 등 생물학적으로 유사한 병리를 지니며 치료약제에 있어서도 높은 유사성을 보인다는 사실로 뒷받침된다. 이러한 점을 고려하면 우울 증상을 호소하며 내 원한 환자의 TCI와 DSQ 검사를 통해 환자의 치료 계획을 세 우고 향후의 경과를 예측하는 데에 도움될 것으로 기대한다. 이러한 근거를 더 확고히 하기 위해 향후 다양한 척도와 질환 군을 대상으로 추가적인 연구가 필요할 것으로 생각되며, 우 울과 불안 사이의 유사성과 차이점 등 증상 간의 관계에 대해 서도 다양한 방향의 접근을 해 볼 수 있을 것이다.

\section{Acknowledgments}

None

\section{Conflicts of Interest}

The authors have no potential conflicts of interest to disclose.

\section{Author Contributions}

Conceptualization: all authors. Data curation: all authors. Formal analysis: all authors. Investigation: all authors. Methodology: all authors. Project administration: Bon-Hoon Koo. Resources: all authors. Supervision: Bon-Hoon Koo. Validation: all authors. Visualization: all authors. Writing — original draft: all authors. Writingreview \& editing: all authors.

\section{ORCID iDs}

\section{Bon-Hoon Koo https://orcid.org/0000-0001-9633-3835}

Jin-Woo Kim https://orcid.org/0000-0002-2204-427X

\section{REFERENCES}

Andrews G, Singh M, Bond M. The defense style questionnaire. J Nerv Ment Dis 1993;181:246-256

Beck AT, Epstein N, Brown G, Steer RA. An inventory for measuring clinical anxiety: psychometric properties. J Consult Clin Psychol 1988; 56:893-897.

Belzer K, Schneier FR. Comorbidity of anxiety and depressive disorders: issues in conceptualization, assessment, and treatment. J Psychiatr
Pract 2004;10:296-306.

Bond MP, Vaillant JS. An empirical study of the relationship between diagnosis and defense style. Arch Gen Psychiatry 1986;43:285-288.

Bystritsky A, Kerwin L, Feusner JD, Vapnik T. A pilot controlled trial of bupropion XL versus escitalopram in generalized anxiety disorder. Psychopharmacol Bull 2008;41:46-51.

Chung MW, Park SH, Kim SH. A preliminary study for the development of a Defense Style Questionnaire adapted for Koreans. J Korean Neuropsychiatr Assoc 1993;32:707-716.

Cloninger CR. A unified biosocial theory of personality and its role in the development of anxiety states. Psychiatr Dev 1986;4:167-226.

Cloninger CR, Svrakic DM, Przybeck TR. A psychobiological model of temperament and character. Arch Gen Psychiatry 1993;50:975-990.

Cloninger CR, Svrakic DM, Wetzel RD. The Temperament and Character Inventory (TCI): a guide to its development and use. St. Louis, MO: Center for Psychobiology of Personality, Washington University; 1994. p.19-28.

Colovic O, Lecic Tosevski D, Perunicic Mladenovic I, Milosavljevic M, Munjiza A. Defense mechanisms in "pure" anxiety and "pure" depressive disorders. J Nerv Ment Dis 2016;204:746-751.

Compton WM, Conway KP, Stinson FS, Grant BF. Changes in the prevalence of major depression and comorbid substance use disorders in the United States between 1991-1992 and 2001-2002. Am J Psychiatry 2006;163:2141-2147.

Coppen A. The biochemistry of affective disorders. Br J Psychiatry 1967; 113:1237-1264

de Graaf R, Bijl RV, Smit F, Vollebergh WA, Spijker J. Risk factors for 12-month comorbidity of mood, anxiety, and substance use disorders: findings from the Netherlands Mental Health Survey and Incidence Study. Am J Psychiatry 2002;159:620-629.

de Winter RF, Wolterbeek R, Spinhoven P, Zitman FG, Goekoop JG. Character and temperament in major depressive disorder and a highly anxious-retarded subtype derived from melancholia. Compr Psychiatry 2007;48:426-435.

Dunlop BW, Nemeroff CB. The role of dopamine in the pathophysiology of depression. Arch Gen Psychiatry 2007;64:327-337.

Enoch MA, White KV, Waheed J, Goldman D. Neurophysiological and genetic distinctions between pure and comorbid anxiety disorders. Depress Anxiety 2008;25:383-392.

Farabaugh A, Alpert J, Wisniewski SR, Otto MW, Fava M, Baer L, et al. Cognitive therapy for anxious depression in $\operatorname{STAR}(*) \mathrm{D}$ : what have we learned? J Affect Disord 2012;142:213-218.

Fava M, Rush AJ, Alpert JE, Balasubramani GK, Wisniewski SR, Car$\min \mathrm{CN}$, et al. Difference in treatment outcome in outpatients with anxious versus nonanxious depression: a STAR*D report. Am J Psychiatry 2008;165:342-351.

Freud A. The ego and the mechanisms of defence. New York: International Universities Press;1946. p.1-196.

Hamon M, Blier P. Monoamine neurocircuitry in depression and strategies for new treatments. Prog Neuropsychopharmacol Biol Psychiatry 2013;45:54-63.

Heath AC, Cloninger CR, Martin NG. Testing a model for the genetic structure of personality: a comparison of the personality systems of Cloninger and Eysenck. J Pers Soc Psychol 1994;66:762-775.

Hogenelst K, Schoevers RA, Kema IP, Sweep FC, aan het Rot M. Empathic accuracy and oxytocin after tryptophan depletion in adults at risk for depression. Psychopharmacology (Berl) 2016;233:111-120.

Homan P, Neumeister A, Nugent AC, Charney DS, Drevets WC, Hasler G. Serotonin versus catecholamine deficiency: behavioral and neural effects of experimental depletion in remitted depression. Transl Psychiatry 2015;5:e532.

Jokinen J, Nordström AL, Nordström P. The relationship between CSF HVA/5-HIAA ratio and suicide intent in suicide attempters. Arch Suicide Res 2007;11:187-192. 
Jylhä P, Isometsä E. Temperament, character and symptoms of anxiety and depression in the general population. Eur Psychiatry 2006;21:389395.

Kasch KL, Rottenberg J, Arnow BA, Gotlib IH. Behavioral activation and inhibition systems and the severity and course of depression. J Abnorm Psychol 2002;111:589-597.

Kennedy BL, Schwab JJ, Hyde JA. Defense styles and personality dimensions of research subjects with anxiety and depressive disorders. Psychiatr Q 2001;72:251-262.

Kessler RC, Berglund P, Demler O, Jin R, Merikangas KR, Walters EE. Lifetime prevalence and age-of-onset distributions of DSM-IV disorders in the National Comorbidity Survey Replication. Arch Gen Psychiatry 2005;62:593-602.

Kessler RC, Sampson NA, Berglund P, Gruber MJ, Al-Hamzawi A, Andrade L, et al. Anxious and non-anxious major depressive disorder in the World Health Organization World Mental Health Surveys. Epidemiol Psychiatr Sci 2015;24:210-226.

Korea Centers for Disease Control \& Prevention. Trends in prevalence of depressive disorder among Korean adults aged 19 years and over, 2014 and 2016 [updated 2019 Sep 10; cited 2018 Sep 20]. Available from: http://www.cdc.go.kr/board.es?mid=a20602010000\&bid=0034 \&act=view\&list_no=140810\#.

Matsudaira T, Kitamura T. Personality traits as risk factors of depression and anxiety among Japanese students. J Clin Psychol 2006;62:97109.

Minelli A, Pedrini L, Magni LR, Rotondo A. Personality traits in an italian sample: relationship with anxiety and depression. Clin Pract Epidemiol Ment Health 2009;22;5:26-30.

Nautiyal KM, Hen R. Serotonin receptors in depression: from A to B. F1000Res 2017;6:123.

Novick JS, Stewart JW, Wisniewski SR, Cook IA, Manev R, Nierenberg AA, et al. Clinical and demographic features of atypical depres- sion in outpatients with major depressive disorder: preliminary findings from STAR*D. J Clin Psychiatry 2005;66:1002-1011.

Reader BF, Jarrett BL, McKim DB, Wohleb ES, Godbout JP, Sheridan JF. Peripheral and central effects of repeated social defeat stress: monocyte trafficking, microglial activation, and anxiety. Neuroscience 2015;289:429-442.

Rush AJ, Trivedi MH, Wisniewski SR, Nierenberg AA, Stewart JW, Warden D, et al. Acute and longer-term outcomes in depressed outpatients requiring one or several treatment steps: a STAR*D report. Am J Psychiatry 2006;163:1905-1917.

Schneier FR, Liebowitz MR, Abi-Dargham A, Zea-Ponce Y, Lin SH, Laruelle M. Low dopamine $\mathrm{D}(2)$ receptor binding potential in social phobia. Am J Psychiatry 2000;157:457-459.

Shin LM, Liberzon I. The neurocircuitry of fear, stress, and anxiety disorders. Neuropsychopharmacology 2010;35:169-191.

Spinhoven P, Kooiman CG. Defense style in depressed and anxious psychiatric outpatients: an explorative study. J Nerv Ment Dis 1997;185:8794

Stallings MC, Hewitt JK, Cloninger CR, Heath AC, Eaves LJ. Genetic and environmental structure of the Tridimensional Personality Questionnaire: three or four temperament dimensions? J Pers Soc Psychol 1996; 70:127-140

Sung SM, Kim JH, Yang E, Abrams KY, Lyoo IK. Reliability and validity of the Korean version of the Temperament and Character Inventory. Compr Psychiatry 2002;43:235-243.

Wittchen HU, Kessler RC, Pfister H, Lieb M. Why do people with anxiety disorders become depressed? A prospective-longitudinal community study. Acta Psychiatr Scand 2000;102(Suppl 406):14-23.

Yook SP, Kim ZS. A clinical study on the Korean version of Beck Anxiety Inventory: comparative study of patient and non-patient. Korean J Clin Psychol 1997;16:185-197. 